\title{
THE UNIONIZATION OF THE AMERICAN STEEL INDUSTRY
}

If there is any single series of events in American labor history which may be characterized as of momentous import, it is the unionization of steel. After a crushing defeat by the United States Steel Corporation in I90I, the Amalgamated Association of Iron, Steel and Tin Workers, A.F. of L., had eked out a precarious and meager existence. Unsuccessful organizing campaigns in 1919-20 and in 1933 left the Amalgamated the mere shell of an organization. Average membership in 1935 was only 9,869; in that year, 84 local lodges had been disbanded, and only four new ones established. Not a single national organizer was in the field. ${ }^{1}$ Against this unpromising background the great drama that was to convert the citadel of antiunionism in the United States into a highly organized industry unfolded swiftly with the formation of the Committee for Industrial Organization in the closing days of the year 1935 .

\section{CAPTURE OF THE AMALGAMATED BY THE C.I.O.}

The 1934 convention of the A.F. of L. had directed its Executive Council "at the earliest practical date [to] inaugurate, manage, promote and conduct a campaign of organization in the iron and steel industry."2 When it came to implementation of this mandate, however, serious differences of opinion on appropriate procedure were manifest among the Executive Council members. In January, I935, William Green asked M. F. Tighe, president of the Amalgamated Association, to draw up a plan of organization for consideration by the Executive Council. In his reply, Tighe stated that a minimum of $\$ 200,000$ would be required to start a new campaign, and added: "We are firmly

1 Amalgamated Association of Iron, Steel and Tin Workers, Annual Reports of International Officers to the 6rst Annual Convention, 1936, pp. 22, I13.

2 American Federation of Labor, Report of Proceedings of the Fifty-Fourth Annual Convention, 1934, P. 587 . 
convinced by the experience of the past 18 months that to make any headway, plants must be organized industrially." 1

There was lack of unanimity among the top A.F. of L. leadership on the appropriate manner of implementing this resolution. William Green, president of the A.F. of L., supported strongly by John L. Lewis, head of the United Mine Workers of America, argued that it was futile to expect organization on anything but an industrial unit basis, i.e., that all workers in a plant must belong to the same union, rather than being split up craftwise. However, the dominant craft leaders of the A.F. of L., led by Wharton of the Machinists and Hutcheson of the Carpenters, refused to countenance any plan of organization which would entail a waiver of jurisdiction by any one of the existing 109 unions affiliated with the A.F. of L., many of which had claims to portions of the steel industry. The upshot was that Green received authorization to inaugurate a joint organizing campaign on behalf of all unions claiming jurisdiction in steel, a result that was far from pleasing to the proponents of industrial organization, and particularly to Mr. Lewis.

Very little was accomplished during 1935. In its report to the 1935 convention, the A.F. of L. Executive Council asserted that "plans can now be formulated and organizing policies adopted so that an effective organizing campaign can be launched among the workers employed in the steel industries of the nation at the earliest possible date. The Executive Council is thoroughly alive to the situation. It is its purpose and determination to carry out the instructions of the San Francisco Convention to launch and conduct an organizing campaign in the iron and steel industry." 2

John L. Lewis had decided, however, that the A.F. of L. was not going to act in an effective manner. At a meeting with a few associates held in May, 1935, he made it clear that as long as steel remained unorganized, the coal miners, many of whom were employed by the steel companies in the "captive" mines, found their organization in jeopardy. No definite plans were adopted, and one of those present at the meeting was of the opinion that Lewis was waiting upon the outcome of the 1935 A.F. of L. convention before deciding upon a course of action. ${ }^{3}$

The steel situation was uppermost in the minds of those who debated the issue of industrial unionism at the 1939 convention. Lewis asserted

1 Amalgamated Association of Iron, Steel and Tin Workers, Annual Reports of International Officers to the 6ist Annual Convention, 1936, p. 23.

2 American Federation of Labor, Report of the Proceedings of the Fifty-Fifth Annual Convention, 1935, p. 97.

8 Interview with John Brophy, March 19, 1955. 
that he had been told by officers of the United States Steel Corporation that they opposed collective agreements in the captive mines because they feared the consequent spread of unionism into the steel industry itself. He castigated the Executive Council for its inactivity in the following terms:

"We are assured the way is now open for an aggressive campaign of organization in the steel industry. What kind of a campaign - a campaign to organize them in fifty-seven varieties of organizations? You ought to know without my telling you how effective that kind of campaign will be, and with several hundred thousands of members of the United Mine Workers of America who understand the positions of interests of that character and who also understand the practical problems of organization in these big industries, they know that the officers of the American Federation of Labor might as well sit down in their easy chairs and twiddle their thumbs and take a nap as to conclude that any results will come from that kind of organization in the iron and steel industry." 1

Philip Murray, vice-president of the Miners' Union, told of the loss of 8,000 employees of the Jones and Laughlin Steel Co. at Aliquippa, who had organized themselves into an independent industrial union but refused to accept craft charters. ${ }^{2}$ But the convention merely approved the report of the Executive Council and ordered that the resolution adopted the year before be effectuated. Leonard, the secretary-treasurer of the Amalgamated, was directed by the Executive Council to prepare a specific, precise plan of organization.

Such a plan was submitted to the Executive Council in January, 1936. It stressed the necessity of an appropriate preliminary publicity campaign, and of concentrating upon the United States Steel Corporation. The Executive Council of the A.F. of L. would manage the campaign, but organization was to be in local lodges of the Amalgamated. There was very little of a practical nature in the proposal. The Amalgamated seemed to be mainly interested in the level of dues to be charged new members, and in the prevention of any dilution of its existing scheme of death benefits. ${ }^{3}$

The A.F. of L. was finally convinced that nothing could be expected of the Amalgamated. The Executive Council bluntly rejected the plan as neither satisfactory nor practical, and directed Green to prepare and

2 American Federation of Labor, Report of Proceedings of the Fifty-Fifth Annual Convention, 1935, p. 539.

Ibid., p. 562 .

3 For the text of the proposal, see Amalgamated Association of Iron, Steel and Tin Workers, Annual Reports of International Officers to the 6ist Annual Convention, 1936, p. 132. 
submit to the affiliated unions a specific plan for a one-year campaign to include an estimate of the monthly per capita cost to each participating union, and a structural scheme based upon joint councils as a temporary organizing device, with the ultimate recognition of the jurisdictions of all interested unions. ${ }^{1}$

However, this action came too late. Immediately upon its organization in November, 1935, the C.I.O. began to interest itself in steel. In January, 1936, John Brophy publicly urged the A.F. of L. Executive Council to take immediate action in steel, warning that "serious consequences may result if the Council does not remove the present barriers to organization of these workers in the type of unions they desire...." 2 This was followed by a widely publicized letter of February 22, 1936, from Lewis and Howard, president of the Typographical Union, to Green, in which the C.I.O. pledged \$500,000 toward a steel organizing fund of $\$ 1,500,000$ to be raised by the A.F. of $\mathrm{L}$. under the following conditions:

"I. Organization must be along industrial lines. Past experience has shown that large numbers of steel workers can be brought into one organization by united and well-timed effort, but that organization breaks up and disappears when the workers are threatened with division into a multitude of craft unions. We therefore require assurance that all steel workers organized will be granted the permanent right to remain united in one industrial union.

2. The leadership of the campaign must be such as to inspire confidence of success. There must be placed in charge a responsible, energetic person, with a genuine understanding of the steel workers problems, who will work in conjunction with an advisory committee representative of the unions supporting the drive."3

This letter provided the first inkling of a technique of labor organization of which John L. Lewis may fairly be designated as the originator, namely, the huge organizing campaign financed by millions rather than hundreds of dollars. A.F. of L. unions had contributed approximately $\$ 500,000$ to the 1919 steel drive, but this was primarily for strike relief rather than for organizing work. Similar large sums of money had been raised to assist coal miners in their strikes, but again for humanitarian rather than purely organizational purposes.

1 American Federation of Labor, Report of the Proceedings of the Fifty-Sixth Annual Convention, I936, p. 86.

2 Union News Service, January 20, 1936.

3 For the full text of this letter, see Proceedings of the Executive Council of the American Federation of Labor in the Matter of Charges Filed by the Metal Trades Department, August 3, 1936, pp. 37-38. 
The $\$ 200,000$ that President Tighe of the Amalgamated had estimated he would need in 1935 to start a new steel campaign had seemed a considerable amount of money to the A.F. of L. Executive Council, but Lewis' offer went far beyond their previous conceptions.

Perhaps as a consequence of this offer, William Green, on March 2, 1936, addressed a circular letter to the heads of all A.F. of L. unions outlining a plan for organizing the steel industry. He urged the creation of a fund of $\$ 750,000$ to be raised by contributions from affiliated unions, to be placed at the disposal of the American Federation of Labor, which would direct the campaign in cooperation with the Amalgamated. Immediate replies were requested with indications of how much money would be forthcoming. ${ }^{1}$ The C.I.O. offer was not acted upon, since the conditions specified were obviously unacceptable to the A.F. of L.

One of the first replies to the A.F. of L. appeal came from Wharton in his capacity as president of the powerful Machinists' Union. He told Green that there could be no reasonable hope of success as long as the C.I.O. group remained in the A.F. of L., and refused any financial support until such time as all affiliates of the A.F. of L. were behind the Green plan. ${ }^{2}$ Other responses were equally discouraging. As soon as the Wharton refusal to contribute had been made public, Lewis urged Tighe to enter into a joint committee with the C.I.O., and promised that the industrial jurisdiction of the Amalgamated would be respected. ${ }^{3}$

This offer placed the leaders of the Amalgamated in a quandry. The A.F. of L. had made no concrete countersuggestions, and, moreover, there seemed no disposition on the part of the Executive Council to interpret the jurisdiction of the Amalgamated nearly as broadly as did the C.I.O. On the other hand, Tighe and his associates were basically loyal to the A.F. of L. and somewhat fearful of John L. Lewis. In an attempt to solve their dilemma, the 1936 convention of the Amalgamated sent a delegation to the A.F. of L. Executive Council, which was in session at the time, with a request for positive action, and in particular, asked for a clarification of the jurisdictional rights of the Amalgamated.

The reply of the Executive Council came in the from of a letter from Green to the Amalgamated convention, on May 8. It reiterated the intention of the A.F. of $L$. to inaugurate and manage an organizing campaign, on the basis of "unconditional" contributions from affili-

1 Proceedings of the Executive Council, Charges Filed by the Metal Trades Department, op. cit., pp. 39-4I.

2 Union News Service, April 13, 1936.

3 Ibid., April 2o, 1936. 
ated organizations. With respect to jurisdiction, the letter stated: "While it is the purpose of the Executive Council to apply the broadest and most comprehensive industrial policy possible due regard and proper respect for the jurisdictional rights of all national and international unions will be observed in the execution of an organizing campaign."1

On the same day, John L. Lewis addressed a telegram to the Amalgamated convention, which read in part:

"A The statement is a rehash of the ancient and futile resolutions adopted from time to time by the American Federation of Labor and the Executive Council, which have resulted in the frittering away of years of valuable time without contributions to the cause of collective bargaining in the iron and steel industry.

B The statement of the Executive Council is obviously filled with venom and malice toward the nine major organizations of the American Federation of Labor which comprise the Committee for Industrial Organization and seeks to exclude those organizations from assisting or contributing to the cost of an organization campaign in your industry.

C The policy of the Executive Council as expressed in the statement would immediately fill your industry with a horde of organizers attached to craft unions, fiercely competing with each other for the new members who might be organized and for the few dollars which might be taken in as initiation fees and dues collections. It would set aside your claim to industry jurisdiction.

D The policy of the Executive Council would preserve the leadership of the organizing campaign in the hands of men who through the years demonstrated their utter incapacity to establish stable organization and modern collective bargaining in the mass production industries."2

Faced with these specific alternatives, there was little choice left to the Amalgamated. On the one hand there was a definite promise of $\$ 500,000$, probably more money than had ever before been pledged for a single organizing campaign. On the other hand, there was merely a vague commitment for a campaign, tied in with the craft threat to the Amalgamated jurisdiction. Although the leadership managed to prevent the convention from accepting the C.I.O. offer outright, a resolution was adopted calling for organization in cooperation with all unions affiliated with the A.F. of L. which conceded the juris-

1 American Federation of Labor, Report of the Proceedings of the Fifty-Sixth Annual Convention, 1936, p. 88.

2 A.F. of L., Proceedings of the s6th Annual Convention, op. cit., pp. 89-9o. 
dictional rights of the Amalgamated and contributed organizers and funds. ${ }^{1}$ But this provided only a short respite for the Amalgamated leadership, and in particular for Tighe, who was exceedingly reluctant to break with the A.F. of L. On May Is, Murray, Brophy, and P. T. Fagan called upon Secretary-Treasurer Leonard and asserted that the C.I.O. was in accord with the resolution of the Amalgamated convention, and was ready to act at a moment's notice, but warned that "the C.I.O. would be forced to inaugurate a campaign to organize the steel workers on its own volition, if it became impossible to arrive at a cooperative understanding with the Amalgamated Association."2 Pressure from the local lodges continued to mount, even from those lodges which had supported the compromise resolution at the convention. ${ }^{3}$ Lewis wrote to Tighe once more on May 21 warning: "The C.I.O. has stated its genuine desire to cooperate with your union in making good its chartered jurisdiction. But a right to jurisdiction ceases to have weight unless it is put into effect." 4

Even under this pressure, the Amalgamated leadership made one last effort to escape the clutches of Lewis. On May 29, an Amalgamated delegation headed by Secretary-Treasurer Leonard met with Green in Washington. The latter indicated that the A.F. of L. intended to place 35 of its own organizers in the field; but "the confusion created by the activities of the Committee for Industrial Organization, and the offer of that Committee to contribute funds conditionally, has caused many of the affiliated unions to withhold the necessary support until the differences existing between the Executive Council and the C.I.O. are adjusted... as the situation now stands it is President Green's opinion that the Executive Council will bide its time for the present."5 The very next day, Leonard wired Lewis for an appointment, which was arranged for June 3 .

At this meeting, the C.I.O. representatives made it plain that the C.I.O. had decided to embark upon an independent campaign if the Amalgamated was not prepared to cooperate. After a day of discussion, the C.I.O. submitted its proposition in writing. Leonard wired Tighe, who was ill and not at the meeting, that C.I.O. aid was contingent upon formal affiliation with the C.I.O., and that a decision

1 Amalgamated Association of Iron, Steel and Tin Workers, Journal of Proceedings of the International Lodge, 1936, p. 2779.

2 Amalgamated Association of Iron, Steel and Tin Workers, Annual Report of International Officers to 62nd Annual Convention, 1937, P 123

3 Robert R. R. Brooks, As Steel Goes, New Haven, 1940, p. 73.

4 Amalgamated Association of Iron, Steel and Tin Workers, Annual Report, 1937, op. cit., p. 125 .

5 Ibid., p. 126. 
would have to be made immediately, whereupon Tighe authorized the Amalgamated delegation to use its own judgment. On June 4, the C.I.O. proposal was accepted, with only a few minor changes.

This document provided for the creation of the Steel Workers Organizing Committee, composed of members designated by the chairman of the C.I.O., two of whom were to be from the Amalgamated. The Committee was to exercise policy functions, and to have exclusive authority to deal with employers. The Amalgamated pledged itself not to take any action affecting the organizing campaign without first consulting the chairman of the Committee. The C.I.O. agreed to provide funds up to $\$ 500,000$, to be disbursed by the S.W.O.C. Dues were fixed at $\$$ I monthly per member, and the S.W.O.C. was empowered to dispense with initiation fees. The Amalgamated retained only the right to issue charters, in effect. The termination of the campaign and the disbanding of the Committee were to be within the joint province of the S.W.O.C. and the C.I.O. - not the Amalgamated.

Why, it may be asked, was the C.I.O. so much concerned with the acquisition of a moribund organization of 10,000 members? The answer must be sought in the powerful concept of "legitimacy" that dominates the American labor movement. In the early months of 1936, the C.I.O. had not yet decided upon its course. The A.F. of L. remained the sole parent federation, and to set up a new steel union would have involved the commission of the cardinal sin of dualism. The Amalgamated, by virtue of its A.F. of L. charter, had the only legitimate right to organize those steel workers who did not fall within the jurisdiction of the craft unions. Some of the members of the C.I.O., in particular David Dubinsky, head of the Ladies' Garment Workers, were not prepared to make a clean break with the A.F. of L. As long as it became part of the C.I.O., the Amalgamated Association of Iron, Steel and Tin Workers could cause little trouble and represented a cheap investment. Within the A.F. of L., it was a potential source of retaliatory power.

THE ORGANIZATION OF THE

UNITED STATES STEEL CORPORATION

With the digestion of the Amalgamated, Lewis moved so surely as to leave little doubt that careful organizational plans had been in preparation for some time. Lewis named as chairman of the Steel Workers' Organizing Committee his long-time lieutenant, Philip Murray, vicepresident of the United Mine Workers. David McDonald, Murray's assistant, was made secretary-treasurer of the Committee. The other 
S.W.O.C. members were Julius Hochman and Leo Krzycki of the Amalgamated Clothing Workers; M. F. Tighe and Joseph K. Gaither of the Amalgamated Association of Iron Workers; P. T. Fagan and Van A. Bittner of the United Mine Workers; and John Brophy, C.I.O. director of organization. ${ }^{1}$ Actually, the Committee as such was never a functioning body; it met occasionally to approve the work of the chairman, but the latter exercised full executive and administrative power. ${ }^{2}$ Clinton S. Golden, a former Amalgamated Clothing Workers organizer who had been affiliated with Brookwood Labor College, was appointed director of the important northeastern region, while the western and southern regions were headed by two Mine Workers' officials, Van A. Bittner and William Mitch. Twelve international representatives of the United Mine Workers were detailed to the S.W.O.C. staff, and these were to be supplemented by men working out of the U.M.W.A. districts.

At the first meeting of S.W.O.C., held on June 17, 1936, Murray estimated that monthly expenditures would run about $\$ 45,000$ a week, since the hiring of 100 organizers was contemplated. ${ }^{3}$ Initiation fees were waived, since it was the experience of the C.I.O. leaders that they were an obstacle to organization, and dues were fixed at $\$$ I a month, payable in advance. ${ }^{4} \mathrm{~A}$ statement was issued emphasizing that the S.W.O.C. was under the direction of representatives of established unions with successful collective bargaining records, and that its purpose was to avoid industrial strife if employers demonstrated a reasonable spirit of cooperation. ${ }^{5}$ On August r, Steel Labor, the official newspaper of the S.W.O.C., began publication.

Reporting to the second meeting of the S.W.O.C. in Pittsburgh, on September 29, 1936, Murray reviewed succinctly the various steps necessary to launch the Committee as an effective organizing device:

"There are three distinct stages through which this campaign must go before we reach the stage of negotiations. The first stage consisted of setting up the organizing machinery necessary to do the job. We recruited a staff of men who had to make contacts in the mills, become adjusted to a new situation and develop their organizing activities according to local conditions - but always under the strict and close supervision of the regional director and the national office. The second step consisted of using our organizing machinery to put our message across...

1 Union News Service, June 15 , 1936.

2 Interview with John Brophy, March 19, 1955.

${ }^{3}$ Minutes of the Organizational Meeting of the Steel Workers' Organizing Committee (typewritten), Pittsburgh, June $\mathrm{x} 7, \mathrm{x} 936$.

4 Union News Service, June 22, 1936.

5 Ibid. 
.... we begin - and we are just beginning - to enter the third stage. It is the job of organizing, signing up members, establishing lodges."1

Murray told the Committee that 35 subregional offices had been established, with i 88 full-time and 80 part-time employees. Disbursements up to that time totalled $\$ 186,00$, while membership was I 5,306 , most of the members having been inherited from the Amalgamated. Some of the organizers were drawn from the staff of the Mine Workers' Union, but many came from other industries and owed their primary loyalty to Murray rather than to John L. Lewis, which was to stand the former in good stead when the two men broke five years later.

It was soon made clear that the role of the Amalgamated Association was to be a minor one, and that the S.W.O.C. was by all odds a completely new organization. While charters were formally issued by the Amalgamated, this was a mere ministerial act, for they were issued in the name of S.W.O.C. Where there was an Amalgamated lodge, but no collective agreement, the local was taken over by the S.W.O.C., in return for which the S.W.O.C. agreed to continue per capita payments to the Amalgamated equal to the average per capita paid from July I, 1935, to June 30, 1936. Five local lodges in Portsmouth, Ohio, and four in Cleveland were transferred in this way to the S.W.O.C., the Amalgamated officers justifying this action on the ground that "it was either a question of turning them over to S.W.O.C. whose resources permitted a proper approach to the task of organizing them, or losing what organization they had maintained through the bitter strife and company opposition." 2 There was some bad feeling about these events. Edward W. Miller, a vice-president of the Amalgamated, who had been fairly consistently pro-C.I.O. in the earlier negotiations, complained to Murray that the take over of locals was destroying the Amalgamated. ${ }^{3}$ And Tighe wrote rather plaintively that "the taking over of the organization of the steel industry by the Commitee for Industrial Organization and placing it in the hands of what is known as the Steel Workers' Organizing Committee, practically took all organizing of steel workers out of the jurisdiction of our Association"4

In planning its campaign, the S.W.O.C. faced an industry with approximately 479,000 wage earners ${ }^{5}$, one with a long reputation as 1 Minutes of a Meeting of the Steel Workers' Organizing Committee (typewritten), September 29, 1936 .

- Amalgamated Association of Iron, Steel and Tin Workers, Annual Report of International Officers to 62nd Annual Convention, April, 1937, Pp. 139, 160.

3 Ibid.,p. 339 .

4 Ibid., p. 3 .

s U.S. Senate, $77^{\text {th }}$ Congress, ist Session, Committee on Education and Labor, Report No. 151, 1941, p. 10. 
the stronghold of the open shop in the United States. A high degree of concentration prevailed, with five concerns dominating the, industry. ${ }^{1}$ Employment, like output, tended to be concentrated in large steel works and rolling mills. In 1937, 58.2\% of all steel wage earners were employed in 53 establishments, each of which employed in excess of 2,500 persons. ${ }^{2}$

By far the largest concern in the industry was the United States Steel Corporation, with some 222,000 employees and about 35 per cent of the nation's rolling mill capacity. Next in order of size came Bethlehem Steel, with 80,000 employees and I4 per cent of capacity; Republic Steel, 49,000 employees and 9 per cent of capacity; Jones and Laughlin, 29,000 employees and 5 per cent of capacity; and Youngstown Sheet and Tube. ${ }^{3}$

After World War I, a number of steel companies introduced employee representation plans, the so-called company unions, into their plants. Perhaps the most important of these was the Bethlehem Steel Plan, which was established in I918, and served as the model for others. The United States Steel Corporation, however, did not resort to the company union until the enactment of the National Recovery Act in 1933, when this form of employee representation was inaugurated at each of its plants. Even before the advent of the S.W.O.C., some restlessness was manifested among the company unions, particularly in the less well-established organizations of the United States Steel Corporation. In January, 1936, a majority of the employee representatives of the U.S. Steel Carnegie-Illinois plant at Gary, Indiana, secured a charter as a local lodge of the Amalgamated. ${ }^{4}$ In March, company union representatives of several Carnegie-Illinois plants in the Pittsburgh-Youngstown area established a local joint council for the purpose of making the company unions more effective, in defiance of management desires.

This activity in the company unions was by no means the creation of the S.W.O.C., although the union capitalized upon it. A veteran observer wrote, four months before the formation of S.W.O.C.:

"First... many individual steel workers have, just now, a sense of freedom that has been notably absent from the steel mills since

1 In 1929, the five largest firms controlled 68.2 per cent of the steel ingot capacity of the industry, a pattern of concentration which remained approximately unchanged in 1936 . 2 Report No. I I I, I941, op. cit., p. Io.

3 The employment data, which include white collar employees as well as wage earners, are from Gertrude G. Schroeder, The Growth of Major Steel Companies, I900-1950, Johns Hopkins University, 1952, pp. 216-222. Capacity data, which are for the year 1938, are from Temporary National Economic Committee, The Structure of Industry, Monograph No. 27, I94I, p. 258.

4 Edward Levinson, Labor on the March, New York, 1938, p. 192. 
the Homestead strike of 1892 ; second... this sense of freedom is resulting in certain steps in the direction of independent, collective action of a type that has been equally rare. And there is a third astounding fact: These steps toward independence are being taken where few had thought ever to see such a thing take place - in the company unions."1

Arthur H. Young, vice-president of U.S. Steel, was quoted as saying of these developments:

"...7-a and the Wagner law have stiffened the backbone of the workers. At the same time, it would avail us nothing to buck prevailing sentiment. These movements in the direction of a wider area of collective action are absolutely inevitable and we don't propose to try to stop them. We intend to go along and by evidencing our sincerity of purpose keep matters from getting beyond the point of reasonable negotiation."2

The obvious initial strategy of the S.W.O.C. was to invade the company unions, for they were the only real centers of organization in the industry. Philip Murray explained the S.W.O.C. policy as follows:

"It was apparent to us that to make any progress in steel we had first to 'capture' these company unions. We realized that a great many of the employee representatives, perhaps the majority, were men honestly interested in doing a good job under the Plan which had been imposed upon them and their fellow employees. Our job was to show these men what real unionism meant. To denounce them all as company agents or stooges would be both untruthful and poor strategy." 3

The S.W.O.C., as a first step, sought to enlist the support of influential members of the company unions. Once key men had been secured, the following strategy was adopted: ${ }^{4}$

I. The grievance procedure of the employee representation plans was used to push individual grievances as strongly as possible. If the cases were won, the "progressives" received the credit; if they were lost, the prestige of the plans suffered.

2. The S.W.O.C. supporters insisted upon verbatim reporting of employee representation council meetings. Portions of these records favorable to the S.W.O.C. side were later used for publicity purposes.

1 John A. Fitch, A Man Can Talk in Homestead, in Survey Graphic, February, 1936, p. 7 I.

2 Loc. cit. - The term " $7-a$ " refers to Section 7 -a of the National Industrial Recovery Act (1933).

3 Steel Workers' Organizing Committee, Proceedings of the First Wage and Policy Convention, 1937, p. 3 I.

4 Brooks, op. cit., pp. 92-94. 
3. Enlargement of the committee system under the plans was pressed, with the pro-S.W.O.C. faction seeking to gain key positions on the committees.

4. Wage and hour demands were made persistently as a means of helping to raise the interest of workers in unionism.

The focal point of the S.W.O.C. attack was in the relatively independent employee representation plans of U.S. Steel. Toward the end of August, 1936, the Pittsburgh-Youngstown council, representing 48,000 workers, pressed Carnegie-Illinois for a wage increase, followed shortly by similar demands raised by Plan representatives in the Homestead plant of the same company. Representatives of 12 tin mills of Carnegie-Illinois met in Pittsburgh and resolved in favor of a $\$$ a day minimum, plus a general increase of $\$ \mathrm{r}$ a day. ${ }^{1}$ Benjamin $\mathrm{F}$. Fairless, at the time president of Carnegie-Illinois, replied in a public letter dated September 8 that the financial position of the company did not permit of any general wage increase at the time. Philip Murray seized the opportunity to back the company union demands, arguing in a long public statement that the profit position of the corporation was adequate to meet the workers' demands. ${ }^{2}$ For their part, the Pittsburgh company unions expressed dissatisfaction with Fairless' statement, and renewed their demand for a $\$ s$ a day minimum, the S.W.O.C. program. The Homestead employee representation plan threatened to throw the wage issue into arbitration, which was permitted under the Plan.

The Corporation, concerned with the continuing progress being made by S.W.O.C., moved on two fronts: it attempted to bolster the company unions, and at the same time initiated policy discussions with respect to wages. Plans were laid for the creation of a central joint committee, and on October 19-2 I, 1936, a conference was held for the purpose of establishing the Pittsburgh District General Council. Under this scheme, the Council was to consist of two representatives of each steel plant, and would bargain on an interplant level, something which management had theretofore refused to concede. $^{3}$

On the wage front, Myron C. Taylor, chairman of the board of U.S. Steel, was under pressure from company officials to negotiate a written agreement with employee representatives, and he appointed a committee to study the matter. In a report dated October 13,1936 , the committee recommended that the common labor rate be raised from 47 cents to $\mathrm{S}^{1} / 2$ cents per hour with corresponding increases in other

1 Steel Labor, September 25, 1936, p. I.

2 Ibid., p. 2.

3 Brooks, op. cit., p. 99. 
categories; that one-year contracts be signed with employee representatives embodying the new wage scale; and that wages be tied to the cost-of-living index in the interim. ${ }^{1}$ Announcement of the changes was made on November 6, $1936 .^{2}$

Up to this time, the organizing drive of the S.W.O.C. had made undoubted headway, but the union was still far from the attainment of a commanding position. It claimed a total membership of 82,000 and the allegiance of 1,534 out of 2,500 company union representatives in the industry. ${ }^{3}$ However, the absence of a collective agreement with any important producer rendered dubious the potential membership stability.

The S.W.O.C. altered its strategy at this juncture. Having exploited the employee representation plans to the limit, it moved swiftly in the direction of independent unionism. Charges were filed with the National Labor Relations Board against U.S. Steel, alleging unlawful company domination of the employee representation plans. A conference of 250 company union delegates from 42 plants was held for the purpose of beginning a drive openly to enroll workers in the S.W.O.C.4 The stage of company union infiltration was ended, and the S.W.O.C. now began to press for the breakdown of these organizations.

In an effort to stem the tide, the loyal company unionists at CarnegieIllinois, U.S. Steel's largest operating subsidiary, established a defense committee and solicited funds. ${ }^{5}$ Management agreed to the establishment of an interplant grievance committee known as the "little Supreme Court", with power to visit all Carnegie-Illinois plants for the purpose of investigating failures in the operation of the employee representation plans. On February 16, 1937, the Pittsburgh District Council of Carnegie-Illinois representation plans unanimously asked for another wage increase, borrowing the S.W.O.C. demand for a $\$ 5$ a day minimum, plus an 80 cent per day raise for other workers. ${ }^{6}$ But this late display of militancy by the now thoroughly anti-C.I.O. Employee Representation Council proved

1 Myron C. Taylor, Ten Years of Steel, United States Steel Corporation, 1938, p. 39.

2 The precise amounts of the increase varied from job to job. The percentage increase was to total slightly less than 10 per cent, with individual adjustments to eliminate wage inequities. The sliding scale arrangement tied wages to the cost-of-living index on a quarterly basis. All of the other leading stecl companies made similar adjustments at the same time, though without the sliding scale feature. See Iron Age, November 12, 1936, p. 72.

Steel Labor, November 20, I936, p. r.

4 Steel Labor, January 9, 1937, P. 3.

- The Iron Age, January 7, 1937, p. 192.

- The Iron Age, February 18, 1937, p. 74. It is intimated in the source that CarnegieIllinois was prepared to make a wage adjustment along these lines. 
of little avail; under the impact of unfavorable N.L.R.B. publicity and the organizational momentum of the S.W.O.C., the company unions were losing strength.

The decision of the United States Steel Corporation to recognize the S.W.O.C. rather than to fight, the reversal of a long established policy of resistance to outside unionism, was rationalized by the chairman of its board of directors, Myron C. Taylor, in the following terms:

"It seemed to us that the situation was one in which our principles of representation exactly applied and that the grave danger was in allowing events to proceed to a point where the ordinary rules of reason would not govern. I felt that it was my duty as a trustee for our stockholders and as a citizen to make any honorable settlement that would insure a continuance of work, wages and profits. I discovered that Mr. Lewis was similarly minded and we had an informal preliminary talk. We had the background of the captive coal mine agreements which preserved the principle of representation in connection with union contracts. They had worked very well...

The first talk with Mr. Lewis was on January $9^{\text {th, }}$ 1937, in Washington, D.C. We went into the subject rather thoroughly, but on broad lines. At once on my return to New York, I discussed the whole situation with the available directors, and their unanimous opinion was that I should go ahead with the conversations to the end of reaching an agreement. Mr. Lewis and I continued our conversations on January $\mathrm{I} 3^{\text {th }}$, but did not reach any conclusion that would conform with our policy.

On the I8th of February, in a meeting of the chief officers of our subsidiaries, I discussed the principles involved and asked each of those present whether, if the occasion arose, he would negotiate with the S.W.O.C., and they all answered in the affirmative. I also asked them whether, if an agreement were then reached, they would sign a contract in accord with the practice established with the employee representation groups in the steel plants in November, 1936 . This they also answered in the affirmative.

Mr. Lewis was then in New York and expressed the desire further to explore matters with me, but we had no further meetings until February 25th, when at my house in New York, our conversations were resumed on the basis of this formula which, for the first time, I showed to him: 'The Company recognizes the right of its employees to bargain collectively through representatives freely chosen by them without dictation, coercion or intimidation in any form or from any source. It will negotiate and 
contract with the representatives of any group of its employees so chosen and with any organization as the representatives of its members, subject to the recognition of the principle that the right to work is not dependent on membership or non-membership in any organization and subject to the right of any employee freely to bargain in such manner and through such representatives, if any, as he chooses.'

For a time the negotiations seemed to be off, but on Sunday morning, February 28th, Mr. Lewis and Mr. Murray came to my house with Mr. Moses and, after a short talk, Messrs. Lewis and Murray accepted the formula in principle." 1

The Taylor-Lewis talks were held in the utmost secrecy ${ }^{2}$, and the public announcement of agreement was all the more sensational. The decision of the United States Steel Corporation to recognize the S.W.O.C. must surely rank as one of the critical junctures in American economic history. Not only did it ensure the existence of unionism in the basic steel industry, but it provided inestimable assistance to the C.I.O. in its drive to organize other mass production industries. Even the recognition of the United Automobile Workers Union by the General Motors Corporation a week earlier did not have the impact of the steel settlement, since the G.M. agreement had been reached after a long and bitter sit-down strike, and with the most severe form of pressure exercised by the federal and state governments. Here, on the contrary, there had been virtually no governmental intervention and no industrial strife. The agreement was worked out by the parties themselves on a voluntary basis.

In the agreement, which was signed on March 2, 1937, CarnegieIllinois recognized the S.W.O.C. as the bargaining agent for its members, while the S.W.O.C. agreed not to intimidate or coerce non-union employees into membership. Minimum daily wages were raised to $\$ 5$, and a 4o-hour week was established, with time and a half pay for all hours in excess of 8 per day or 40 per week. ${ }^{3}$ This was supplemented on March 17 with a series of collective agreements covering the several operating subsidiaries of U.S. Steel which contained, in addition to the wage and hour clauses, provisions for paid vacations, seniority, arbitration of grievances, and other standard clauses. 4

Exactly what prompted the Steel Corporation to break so profoundly with its own past cannot be determined without full access to its

1 Myron C. Taylor, op. cit., pp. 40-42.

2 For a background reconstruction of the conversations, see Fortune Magazine, May, 1937, p. 91.

Steel Labor, March 6, 1937, p. I.

- Steel Labor, March 20, I 937 , p. 2. 
policy papers and executive minutes. Among the factors that may have been determining, however, are the following:

I. For the first time since 1930, the Steel Corporation was earning substantial profits. During the years 193 I to 1934 inclusive, net losses were sustained each year. Net income before taxes was $\$$ I 2 million in $1935, \$ 67$ million in 1936 , and $\$ 130$ million in 1937 , compared with $\$ 220$ million in $1929 .{ }^{1}$ The Steel Corporation was certainly desirous of avoiding a strike, which would have interrupted these favorable business developments. Taylor remarked later that "the Corporation subsidiaries, during a very difficult period, have been entirely free of labor disturbance of any kind. The cost of a strike - to the Corporation, to the public, and to the men - would have been incalculable." 2 Moreover, Lord Runciman, president of the British Board of Trade, was in the United States at the time of the Taylor-Lewis talks, arranging for the purchase of steel for Great Britain's rearmament program, and it was rumored that he was insisting upon a guarantee of uninterrupted production before he would let contracts. ${ }^{3}$

2. The costs of a strike, and the chances of success, had to be taken into consideration. It was by no means a foregone conclusion, as some contemporary observers implied ${ }^{4}$, that victory for the union was inevitable or even likely. Little Steel, after all, was able to battle S.W.O.C. to a standstill even after the latter had acquired the funds and prestige that went with recognition by U.S. Steel. Actual S.W.O.C. membership among U.S. Steel employees was neither large nor stable. Lee Pressman, then general counsel of the S.W.O.C., has been quoted as follows on this point: "I don't know what we would have done without Lewis' brilliant move. There is no question that we [the steel workers] could not have filed a petition through the National Labor Relations Board or any other kind of machinery asking for an election. We could not have won an election for collective bargaining on the basis of our own membership or the results of the organizing campaign to date. This certainly applied not only to Little Steel but also to Big Steel." 5 The fact of the matter is that while unfair labor practice charges had been filed with the N.L.R.B., the S.W.O.C. had never filed election petitions for U.S. Steel plants. Moreover, the important Pittsburgh District Council of the representation plans had purged itself of its S.W.O.C. leadership and was on the road to the

1 Gertrude G. Schroeder, op. cit., p. 216.

2 Myron C. Taylor, op. cit., p. 43.

3 Fortune Magazine, May, 1937, p. 92.

4 See, e.g., Edward Levinson, Labor on the March, New York, 1938, p. 199.

5 Saul Alinsky, John L. Lewis, New York, 1949, p. 449. 
achievement of an independent status in order to qualify as a bargaining agent under the National Labor Relations Act. ${ }^{1}$

But if, as seems not at all improbable, U.S. Steel would have been able to defeat the S.W.O.C. in open combat, the cost would undoubtedly have been high. The General Motors plants had just been shut down for six weeks as the consequence of a strike, and a stoppage of similar duration in steel was not at all impossible. Unlike the situation in 1919, the Pennsylvania state administration was, if anything, prounion, and the state police would not have been available for keeping the mills open. Lieutenant-Governor Kennedy, of Pennsylvania, who was secretary-treasurer of the United Mine Workers, had already served notice that state relief would not be withheld from the needy families of striking workers. The Steel Corporation thus had to balance immediate loss of production against the intangible future benefits of freedom from outside unionism, the magnitude of which was diminishing in proportion to the growing militancy of the company unions. Taylor, moreover, may have hoped to trade union recognition against a wage increase, which was reported to be the solution advocated by Little Steel. ${ }^{2}$

3. The current political atmosphere cannot be minimized as a factor. The re-election of Roosevelt in November, 1936, with the strong support of the C.I.O. was widely hailed as a victory for trade unionism. The National Labor Relations Board had opened hearings on alleged company domination of the Carnegie-Illinois employee representation plans, and the La Follette Committee of the United States Senate was threatening to look into labor espionage practices of the Steel Corporation. It was clear from the recent General Motors strike that public opinion would not support forcible suppression of trade unionism.

1 The recognition of the S.W.O.C. by Carnegie-Illinois by no means marked the demise of its company unions. Following the agreement, „the little Supreme Court" met with Benjamin Fairless, president of Carnegie-Illinois, and negotiated a wage increase similar to that accorded the S.W.O.C. The group was also told that the company was prepared to recognize it as the bargaining agent for employees who favored the company unions. This organization appealed to William Green, president of the A.F. of L., for assistance, but failing to get any encouragement from him, approached John P. Frey, head of the A.F. of L. Metal Trades Council. (The Iron Age, March I I, 1937, p. 107.)Frey met with the group and presented a plan for organization along craft lines, which was rejected, and it was decided instead to reorganize as a completely independent outside organization. (The Iron Age, March 18, 1937.) A new organization was formed, called the American Union of Steel Workers, at the end of March. (The Iron Age, April 1, 1937). However, the fledgling organization was given a death blow when Carnegie-Illinois signed an N.L.R.B. stipulation agreeing to disestablish relationships with the existing employee representation plans after the Supreme Court had upheld the constitutionality of the National Labor Relations Act.

Fortune Magazine, May, 1937, p. 179. 
To this may be added the fact that Myron Taylor was cut from quite a different stripe than his predecessor, Judge Elbert Gary, and was much more reconciled to the New Deal than his colleagues in Little Steel. How much his personal philosophy and ambitions had to do with the settlement is problematical, and should not be exaggerated; it is very doubtful that he could have swung his board without convincing economic arguments.

The C.I.O. was jubilant over the agreement. Steel Labor, the organ of the S.W.O.C., wrote in an editorial: „And because of the fine attitude taken by management of Carnegie-Illinois in dealing with the union, the bugaboo of a strike in the industry seems to be put at rest... That was one of the most forward steps ever taken in the history of industrial America."1 John L. Lewis, in for him an unprecedented action, said: "The settlement is a fine example of an intelligent approach to a great economic problem. It has been made possible by the farseeing vision of industrial statesmanship of Mr. Myron C. Taylor, chairman of the board of directors of United States Steel."2 But the reaction of the remaining steel companies was quite different. Tom M. Girdler, president of Republic Steel, later wrote of the agreement: "Unquestionably many thousands of workmen interpreted this event as a wonderful victory for themselves. But I am sure that thousands of workers were shocked, even horrified by the news. Thereafter United States Steel Corporation abandoned its established policy of dealing with employees through an intracorporation union. I was bitter about this. So were a vast majority of the steel men of the nation, including just about everybody from the rank of foreman up in the corporation itself. Why did we not all sign? Simply because we were convinced that a surrender to C.I.O. was a bad thing for our companies, for our employees; indeed for the United States of America. A majority of our employees did not belong to C.I.O. and we were not going to force them in against their wishes." 3

Charles $\dot{M}$. White, an executive officer of Republic Steel, told of having consulted officers of Pittsburgh Steel, Youngstown Sheet and Tube, Jones and Laughlin, and Inland Steel, and found it to be their attitude that "their employees were more in favor of the methods they were then using in collective bargaining than they would be under the C.I.O., or under the S.W.O.C."'4

1 Steel Labor, March 6, 1937, p. 4.

2 Ibid., p. 3.

3 Tom M. Girdler, Boot Straps, New York, 1943, p. 226.

4 U.S. Senate, $77^{\text {th }}$ Congress, ist Session, Violations of Free Speech and Rights of Labor, Report No. I5I, 194x, p. $1 \times 7$. 
If the S.W.O.C. had been under the delusion that its organizing campaign was finished, this was soon dispelled. Within a few months the intention of Little Steel to follow a line other than that adopted by U.S. Steel had become unmistakably clear.

\section{THE LITTLE STEEL STRIKE}

The first fruits of the U.S. Steel victory were not long in coming. During the following month, 5 I companies, including five operating subsidiaries of U.S. Steel, signed with the S.W.O.C. on substantially the same terms. The S.W.O.C., at the end of March, 1937, claimed that it had 200,000 members in 492 local lodges. ${ }^{2} \mathrm{~A}$ month later the union claimed 88 companies under contract, and 280,000 members. ${ }^{3} \mathrm{Be}-$ ginning on April I, dues payments of $\$$ I per month were resumed, and after May $\mathrm{r}$, an initiation fee of $\$ 3$ was imposed for new members, signs that the union felt certain of its ability to attract and hold workers.

As in the case of U.S. Steel, the S.W.O.C. had endeavored to infiltrate and capture the employee representation plans of the smaller steel companies. The evidence is conflicting on the progress that had been made: the union claimed substantial membership among committeemen in Bethlehem ${ }^{4}$, and Jones and Laughlin ${ }^{5}$, but a contemporary observer expressed doubt over S.W.O.C. influence in the wellestablished Bethlehem plan. ${ }^{6}$ The S.W.O.C. also claimed membership at Youngstown Sheet and Tube and Inland Steel, but Republic and Weirton were successful in preventing the spread of union influence among their employees. ${ }^{7}$

At the end of March, 1937, the S.W.O.C. requested bargaining conferences with the non-signing steel companies. The first company with which the union came to grips was Jones and Laughlin, fourth

1 This section is based in large part upon the hearings and reports of a subcommittee of the Committee on Education and Labor of the United States Senate, 74th- $7^{6 \text { th }}$ Congress, under the chairmanship of Senator Robert M. La Follette, Jr. These hearings, which are hereinafter cited as La Follette Committee Hearings, were held over a period of several years. Although at times quite partisan in its efforts to ferret out evidence of what it regarded as wrongful labor practices on the part of the steel companies, the subcommittee nevertheless accumulated thousands of pages of information and testimony relevant to industrial relations in the steel industry during the years 1935 to 1939 .

Steel Labor, April ro, 1937.

${ }^{8}$ Ibid., May I, 1937.

4 The S.W.O.C. claimed two out of three members of a Special Grievance Committee of the Bethlehem employee representation plan, and by April, 1937, 150 out of 250 plan representatives. Steel Labor, January 23, r937; ibid., April ro, I937.

s Steel Labor, January 9, 1937.

- Robert R. R. Brooks, op. cit., p. I35.

7 Loc. cit. 
largest producer in the industry. Its Aliquippa, Pennsylvania, plant had been dubbed "Little Siberia" in trade union circles because of a long record of antiunion actions taken there. Tom Girdler, who had managed the Aliquippa plant of $J$ and $L$ for many years until his departure to head the Republic Steel Company, acknowledged that "The reason Aliquippa was referred to as the 'Siberia of America' was because it was not a popular place for professional union men, and that was because of the men themselves who did not want professional union men there." 1 The National Labor Relations Board found that when the Amalgamated Association had attempted to organize the Aliquippa works in 1934, systematic terror had been employed against it. "Officers of the union and organizers who came into Aliquippa were followed about by the private police of the respondent - the ' $J$ \& $\mathrm{L}$ Police.' The more important union officers were honored by the respondent with permanent shadows and were followed even into the neighboring town of Ambridge where they carried on their activities because of the difficult situation in Aliquippa. The house of Gerstner, the financial secretary, at which an organization meeting had been held, was surrounded day and night by the J \& L Police... Persons coming out of the house were questioned. Some were mysteriously beaten and hit on the head while walking in the streets."2

When the S.W.O.C. approached J \& L with a request for an agreement modeled on that of U.S. Steel, the initial response was negative. H.E. Lewis, chairman of the board of J \& L, entered into negotiations directly with Philip Murray, but no agreement could be reached, whereupon the union called a strike for May $1 \mathbf{~ 2 .}^{3}$ The greater degree of organizing success attained among the employees of this company than in most of the other independent steel companies made it a logical union target. On the eve of the strike the company offered to sign a contract with the S.W.O.C. recognizing it as bargaining agent for its members, with the stipulation that other employee groups could have similar contracts on request. In addition, the company asserted that it would sign an exclusive bargaining contract with the organization obtaining a majority of votes at an N.L.R.B. conducted election. Notwithstanding the fact that this offer was at least as good as the U.S. Steel terms, the union rejected it and the company was shut down. The union was apparently concerned about its ability to win an election ${ }^{4}$, and it may have desired the strike as an evidence of its power, in order to strengthen its position among the workers.

1 La Follette Committee Hearings, pp. 13, 792.

2 In the Matter of Jones and Laughlin Steel Corporation, I N.L.R.B. 503, 1936, p. 503.

3 The Iron Age, May 13, 1937, p. 103.

4 Robert R. R. Brooks, op. cit., p. I 23. 
There was, moreover, considerable restlessness among the workers, and the strike may have taken place without union sanction. ${ }^{1}$ As a reason for rejecting the company offer, the union cited the possibility of delay in holding an N.L.R.B. election, which might afford the company the opportunity of antiunion electioneering.

The success of this strike far exceeded even union expectations. Very few men remained in the mills, and at Aliquippa there was virtually a civil upheaval. The workers were out only 36 hours before an agreement was reached which in all major particulars was identical with the company's initial offer. The stoppage was more a demonstration of political and economic independence on the part of the workers than a labor dispute. A week later, the S.W.O.C. won a 2 to I victory in an N.L.R.B. election, carrying the Aliquippa and Pittsburgh plants of the company by about the same majorities. ${ }^{2}$ In consequence, the S.W.O.C. became the exclusive bargaining representative for 27,000 employees of Jones and Laughlin, the first important company in which it attained such status. For the rest, the contract was substantially similar to the U.S. Steel agreement.

As an immediate consequence of the $J$ and $L$ victory, a number of additional mills signed with the union, among them Crucible Steel and Sharon Steel. At the beginning of June, the S.W.O.C. announced that it had contracts with 142 firms, and a membership of 375,000. It estimated that 70 per cent of the industry had come to terms with $\mathrm{it}^{3}$, a figure which was undoubtedly too high. Organization of the remaining portion of the industry proved much more difficult, and involved a far greater expenditure of resources.

Among the important steel companies which refused to follow the lead of U.S. Steel were Bethlehem Steel, Republic Steel, Youngstown Sheet and Tube, National Steel, Inland Steel, and American Rolling Mills. This group of companies employed about I 86,000 workers. ${ }^{4}$ At the end of March, the S.W.O.C. had addressed a communication to each of the companies, requesting that a U.S. Steel type agreement be executed. In the case of Republic Steel, no answer was received, and on May 3, the union again requested a meeting, this time threatening a strike. A meeting was finally held on May II, following which Republic issued a statement accusing the C.I.O. of attempting to secure a closed shop, and stating it to be company policy to refuse to execute written labor agreements. ${ }^{5}$ On May 20 , the company shut

2 The Iron Age, May 20, I937, p. 72.

2 The Iron Age, May 27, 1937, p. 92.

Steel Labor, June 5, r937, p. r.

- Robert R. R. Brooks, op. cir., p. 134 .

s For the text of this statement, see La Follette Committee Hearings, p. 13908. 
down its Massillon, Ohio, works, and six days later the union declared a strike against the remaining plants of the company.

Negotiations with the other companies followed a similar course. In the case of Bethlehem, an ultimatum was issued on May 7 by the S.W.O.C. giving the company ten days to meet with the union. The period expired with no reply, and after a delay of a month, a strike began on June Ir. ${ }^{1}$ A meeting was held on April 28 between the top S.W.O.C. leadership and the executives of Youngstown Sheet and Tube, at which the company stated that while it would meet and negotiate with the union, it would not sign a contract. In the words of the company itself:

"The point upon which the representatives of the S.W.O.C. and the company did not agree was that of signing an agreement. The company has no written employment agreements and its policy has been and is not to make written agreements of this character....

A written agreement brings no advantages to employees which they do not now possess. It does create an artificial need for labor organization officials to negotiate annually a new agreement as each old one expires regardless of the necessity for any change in the provisions of the agreement. This creates the risk of periodical shutdown during annual negotiations for new agreements". ${ }^{2}$

Two additional conferences were held on a local level, but when they proved fruitless, a strike began on May 26 , on the same day as Inland Steel was shut down. No strikes were called against the remaining holdouts.

Why did the Little Steel companies decide to fight the S.W.O.C. despite the example set by U.S. Steel? Were not the same economic and political considerations involved? What could these firms have hoped to achieve when the giant U.S. Steel had indicated the expedient policy?

I. At the beginning of May, 1937, a sharp decline began in the volume of new business in the steel industry. ${ }^{3}$ While there was no immediate decline in production, the business outlook was somewhat less favorable than it had been at the beginning of the year, when the U.S.

1 La Follette Committee Report No. I5 I, p. 124 . There is some evidence that the calling of this strike was premature, and that the S.W.O.C. would have preferred not to have become embroiled with the second largest producer in the industry until it had finished with Republic and Youngstown, particularly since it was weak organizationally in Bethlehem. The local union called the strike in sympathy with the local employees of a captive railroad controlled by Bethlehem Steel, who had gone on strike the previous day in protest against refusal of the company to bargain.

2 The Iron Age, June 3, 1937, p. 86 A.

3 The Iron Age, May 13, 1937, p. I 7 . 
Steel negotiations were taking place. As the strike progressed, what may have seemed at first like a seasonal decline in new orders began to look more serious. ${ }^{1}$ It may be surmised that whatever effect immediate business prospects had upon the decision of the Little Steel companies to take strikes, their determination to resist once the strikes were under way was strengthened by current economic conditions.

2. Principled opposition to trade unionism appears to have been a major factor in the determination of Little Steel to fight. The sincerity of such men as Tom Girdler, who was the leader of the Little Steel group in its dislike of unionism ${ }^{2}$, is not to be doubted. A few quotations from his autobiography serve to reveal something of the philosophy of the man:

"An employer or a manager of a business can hire or fire, justly or unjustly. All of us would welcome the invention of an arrangement that would eliminate injustice from the relationship. However, even a tyrannical businessman's tyranny is limited to the enterprise he runs. But if the C.I.O. embraces all workers - and John L. Lewis was openly striving for that goal - then no American could work except by permission of this pompous ruler. Republic's workers knew that in 1937 . We who run the company never fooled ourselves that these people on our payrolls were fighting chiefly for Republic Steel Corporation when they resisted Lewis and his mobs. They were fighting for themselves."3 "Tolerance for socialistic propaganda has increased in this country because Americans who know better have not sufficiently resisted the idea that a man with payroll responsibilities is necessarily less of a humanitarian than people of prominence without such responsibilities... The mere fact that Eugene Grace, Frank Purnell and I were heads of big corporations put a tag on us. We were 'bosses'. It is impossible to be a boss and be popular with everybody. If Grace, Purnell and Girdler had been other than resolute men we would not have been running big industrial organizations. Because we were resolute men who understood not

1 It is difficult to trace precisely the curve of economic activity for the industry during the period of the strike because of the influence of the strike itself. The evaluation in the text is based upon discussion of the business outlook that appeared in The Iron Age, the weekly trade publication of the steel industry.

2 On May 27, 1937, the day after the outbreak of the strike, Girdler was elected president of the American Iron and Steel Institute. Eugene Grace, the outgoing president, remarked cryptically that "there was a real contest in this election and you will appreciate the choice of the directors," and ,it was left to his listeners to assume that present labor policies in the industry had an influence in the election of new officers." (The Iron Age, June 3, 1937, p. 32.)

Tom M. Girdler, op. cit., p. 317 . 
only our duty to our stockholders, but our duty to our workers and likewise to our country, we did not surrender. We did not sign."1

3. The Little Steel companies must have felt, with justification, that they were capable of defeating the S.W.O.C. The S.W.O.C. had been able to make less headway in such Little Steel towns as Johnstown, Pennsylvania, and the steel mills of Ohio, than in Pittsburgh or Homestead, where there was at least a tradition of unionism. Moreover, the contemporary split in the labor movement deprived the S.W.O.C. of labor support that might have turned the scales. "My own observations.... convince me," wrote one commentator, "that it was the absence of A.F. of L. support in strategic steel centers - notably Youngstown, Massillon, and Canton - that brought about the weakening of the strike and strengthened the back-to-work movement. The split at the top ran down to cleavages between the newer recruits to the C.I.O. steel union and the older more experienced craft unionists in their localities. I find it difficult to believe that had the Ohio State Federation of Labor and the local union councils given the steel strike whole-hearted support, it could have failed."2

In short, Little Steel was convinced that the cost of winning a strike was outbalanced by the future gains that would accrue from the absence of trade unions in the mills. The ideological convictions of the Little Steel leaders served to augment the value of the expected flow of future benefits.

The actual events of the Little Steel strikes, which were among the most bitter ever fought in the United States, fill several thousand pages of testimony before the $\mathrm{La}$ Follette Committee. The most notorious episode of the entire series of events took place a few days after the inception of the strike, the so-called "Memorial Day incident". ${ }^{3}$ On May 30, 1937, near the plant of the Republic Steel Company in Chicago, Io people were killed and 125 others, including 35 police, were injured. For several days prior to May 30 there had been some picketing of the plant by strikers who were endeavoring to induce nonstrikers to leave. A number of arrests had been made, but the police had enunciated no fixed policy on picketing.

On May 30, after a mass meeting at strike headquarters, it was decided by the strikers to march to the plant to establish a mass picket line. The police asserted later that the purpose of the marchers was to storm the police lines and assault the plant. The Senate Committee

1 Tom M. Girdler, op. cit., pp. 358-359.

2 Pierce Williams, Essence of the Steel Strikes, in Survey Graphic, October, 1937, p. 516.

3 The facts concerning this incident are primarily from United States Senate, $77^{\text {th }}$ Congress, Ist session, Committee on Education and Labor, Report No. 46, Part 2, 1937. 
found, however, that "the evidence not only refutes the police charge that the parade assumed a military character, but establishes, on the contrary, that it lacked all of the elements which would indicate a preconceived plan to employ violence."1

As the marching strikers approached the police line, violence broke out. On the basis of the evidence of scores of eyewitnesses, as well as moving pictures taken by a photographer on the spot, the Committee concluded that "the first shots came from the police; that these were unprovoked, except, perhaps, by a tree branch thrown by the strikers, and that the second volley of police shots was simultaneous with the missiles thrown by the strikers."2 After the first shots had been fired, the strikers broke and ran. The police pursued them with the following results:

"Ten marchers were fatally shot. Seven received the fatal wound in the back, three in the side, none in front. Some of those fatally shot also received severe lacerations and contusions.

Thirty others, including one woman and three minors, received gunshot wounds... Twenty-eight marchers received lacerations and contusions of the head, shoulders and back requiring hospitalization, and between 25 and 30 others received injuries requiring medical treatment...

As against the injuries and fatalities suffered by the marchers, the police-accident and hospitalization records report 35 policemen injured, none shot. Nine of these received hospital treatment, although six of the nine were ambulatory, so that only three were actually hospitalized... The nature of the police injuries does not argue that the marchers put up marked resistance to the police; the medical testimony of the nature of the marchers' wounds indicates that they were shot in flight....

The police were free with their use of clubs as well as guns... Suffice it to say that the evidence, photographic and oral, is replete with instances of the use of clubs upon marchers doing their utmost to retreat, as well as upon those who were on the ground and in a position to offer no show of resistance....

The uncontradicted photographic and oral evidence, corroborated by admissions of the police themselves, establish that their treatment of the injured was characterized by the most callous indifference to human life and suffering. Wounded prisoners of war might have expected and received greater solicitude.... The police dragged seriously wounded, unconscious men along the

1 Committee on Education and Labor, op. cit., p. r4.

2 Ibid., p. 21. 
ground with no more care than would be employed on a common drunkard."1

By June I4, normal operation of the plant had been resumed. 2 Serious disturbances took place in other strike areas. In Massillon, Ohio, police opened fire on the headquarters of Republic Steel strikers, killing and injuring a number of strikers without themselves sustaining any losses. ${ }^{3}$ At Youngstown, Ohio, a steel center where plants of Republic and Youngstown Sheet and Tube are located, a back-towork movement supported by a so-called citizens' committee, which had close ties with the companies, was employed effectively in breaking the strike. The local traffic commissioner was quoted as making the following "typical" remark on the resumption of work: "We have broken the back of Bolshevism in America right here in the Mahoning Valley."4 In a sober appraisal of the Youngstown strike, The Iron Age stated that "from a practical point of view, steel manufacturers in the group opposed to signing contracts seem to have chosen a strategic battleground in selecting Youngstown, the capital of the independent steel industry. Union leaders found disadvantages. Railroads and the Mahoning River shut off many of the big Mahoning Valley plants from access to the streets. Lack of nearby members of the United Mine Workers Union.... for picket purposes, as in some Pennsylvania mill areas, added to their difficulties. Other obstacles which exist in the Youngstown area, as compared with some steel areas in other states, include a lack of relief funds which might support an indefinite shutdown if substantial enough even to maintain soup and bread lines. There are no other industries of size in the Youngstown area to which the striking mill workers can turn as the shutdown of their own mills continues." 5

At Johnstown, Pennsylvania, the pro-union attitude of Governor Earle counterbalanced the pro-employer actions of local officials, but it was not sufficient to overcome initial organizational weaknesses among the Bethlehem Steel workers, and the strike was doomed almost from the start. At Monroe, Michigan, the Republic Steel strikers were admittedly in a small minority. A strike against an Inland Steel plant at Indiana Harbor, Indiana, was ended on July I through the intermediation of Governor Townsend of Indiana. An agreement was reached in which the company recognized the S.W.O.C. as bargaining

1 Committee on Education and Labor, Report No. 46, Part 2, 1937, pp. 3 1-34.

2 The Iron Age, June I 7, 1937 , p. 94.

3 Committee on Education and Labor, Report No. 46, Part 2, 1937, p. 252.

4 The Iron Age, July I, 1937, p. 66 C.

5 The Iron Age, June 17, 1937, p. $90 \mathrm{~B}$. 
agent for its members and agreed to submit unsettled grievances to the Indiana Commissioner of Labor for arbitration. The question of a signed agreement, however, was left to the National Labor Relations Board, so that the union failed to attain its principal demand ${ }^{1}$, although it did secure a company memorandum on labor policy which approximated the Carnegie-Illinois agreement.

To recapitulate: the strike appears to have been relatively ineffective at Bethlehem Steel, the only period of complete shutdown having been a week when martial law was in effect. The strike proved fairly effective at the Ohio plants of Republic Steel, though its South Chicago plant kept in partial operation, and its Buffalo plant and two Alabama subsidiaries were completely unaffected. Youngstown Sheet and Tube's small Chicago plant, as well as its plant at Indiana Harbor, were completely closed, but the strike was relatively ineffective at its Youngstown plants. The Chicago plant of Inland Steel was closed down. By July I5, 1937, virtually all plants had resumed normal operation, though as late as March, 1938, the S.W.O.C. claimed that between 4,500 and 5,500 men were still out at the Canton and Massillon plants of Republic Steel. ${ }^{2}$

During the course of the strike, mediation efforts were made by the governors of Ohio, Pennsylvania, and Indiana, and by the Federal Government. Federal intervention was initiated on June 17 , when the Secretary of Labor appointed a mediation board consisting of Charles P. Taft, Lloyd K. Garrison, and Edward F. McGrady, to meet with the parties. The board received an initial rebuff when the companies refused to delay reopening of struck plants until the conclusion of mediation efforts. Girdler informed the board "that he would not consent to a term contract because he believed it necessary for the proper operation of his company that they should be in a position to meet the fluctuating price of steel by wage variations if they became necessary." 3 The companies refused to meet with Lewis or Murray, but did agree to meet with local union officials on a plant-by-plant basis, although Bethlehem and Republic took the position that they would not even discuss the question of an oral or written agreement.

The board thereupon made the following settlement proposal to the companies: "The making and signing of an agreement with the unions, to become effective only if the union wins an election; the calling off of the strike and the return of all the men to work, the holding of a secret ballot election in the company's plants by the National Labor Relations Board, the agreement to go into effect if the union wins, and

1 The Iron Age, July 8, 1937, p. I.

2 Steel Labor, March 18, 1938.

3 La Follette Committee Hearings, p. 13938. 
to be torn up if the union loses." 1 This proposal was rejected, and the board gave up its efforts on June 24 .

It is impossible to estimate with any degree of accuracy the costs of the strike either to the companies or to the workers. However, Table I contains some suggestive data. In it, changes in net income from 1936 to 1937 are compared for the companies which were struck and those which were not. While the strike was by no means the only factor in the profit picture, the data suggest strongly that except for Bethlehem Steel, at which the stoppage was of shorter duration and relatively less effective than in the remaining companies, the strike was a costly affair. Republic Steel seems to have been the hardest hit. If it is compared, for example, with National Steel, its 1937 net income was some eight million dollars below the expected level. Comparing it with Jones and Laughlin, which settled with the union, the deficit was about five million dollars. Both Youngstown Sheet and Tube and Inland Steel did worse than the large steel companies unaffected by the strike, although not as badly as Republic, on this basis. (Wheeling, Armco and Crucible were considerably smaller than the remaining seven, and comparisons with them are less valid).

Parenthetically, it may be noted that the strike costs did not end in 1937. As a consequence of National Labor Relations Board proceedings, Republic was eventually obliged to reinstate 5,000 strikers who had been discriminated against, with back pay amounting to a half million dollars, while Youngstown Sheet and Tube incurred a similar cost of $\$ 170,000$. In addition, Republic in. I945 paid $\$ 350,000$ to settle suits brought against it on behalf of strikers who had been killed or injured. ${ }^{2}$

Leaving aside the question of lost wages for the workers, the organizing campaign and the strikes involved the union in substantial outlays. It has been estimated that the S.W.O.C. spent $\$ 2,500,000$ up to the end of the Little Steel strike, the great bulk of which came from the United Mine Workers. ${ }^{3}$ John L. Lewis had in effect invested the treasury of the Miners' Union in the organization of steel, and at the end of 1937 there was legitimate doubt about the wisdom of that investment.

\section{THE FINAL ORGANIZING PHASE}

For reasons of space, subsequent developments can be recounted only very briefly. A major secular decline in business which began in the latter part of 1937 and persisted through 1938 threw the S.W.O.C.

1 La Follette Committee Hearings, p. 1394 r.

2 Vincent D. Sweeny, The United Steelworkers of America (no date).

3 Robert R. R. Brooks, op. cit., p. I60. 
completely on the defensive, and put a temporary end to new organization. Renewal of the collective agreements with U.S. Steel in February, 1938, at a time when the industry was operating at about 30 per cent of capacity, was hailed by the S.W.O.C. as a victory because wages were not cut. Although the union claimed a member-

TABLE I

A Comparison of Net Income Changes from 1936 to 1937 Between Steel Companies Affected by a Strike in 1937 and Those Not Affected

A Companies on strike

\begin{tabular}{cc}
\multicolumn{2}{c}{ Net Income } \\
(thousands of dollars)
\end{tabular}

Bethlehem Steel Corp.

Republic Steel Corp.

24,039

45,654

18,124

17,827

14,847

17,634

Inland Steel Corp.

$\mathrm{I} 6,804$

I 8,187

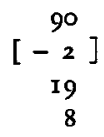

B Companies not on strike

United States Steel Corp.

Jones \& Laughlin Steel Corp. ${ }^{\text {a }}$

$$
\begin{array}{r}
66,702 \\
5,657 \\
18,164 \\
5,961 \\
9,717 \\
4,321
\end{array}
$$

National Steel Corp.

Wheeling Steel Corp.

Crucible Steel Co.
129,585
7,156
26,055
6,326
10,733
5,543

94
27
43
6
10
28

a This company had a strike lasting only 36 hours.

$b$ Net income before interest and income taxes.

Source: Gertrude G. Schroeder, The Growth of Major Steel Companies, 1900-1950, Johns Hopkins University, I95 2, pp. 2 I 6-227.

ship of 500,000 in 1940 , actual dues-paying membership was probably in the vicinity of $225,000 .^{1}$

The first major step forward achieved by the S.W.O.C. in almost three years came in February, 1940, when the Crucible Steel Co., which in 1938 had refused to renew its contract, signed a new agreement recognizing the S.W.O.C. as the representative of its members. ${ }^{2}$ The fact that as late as 1940 , the S.W.O.C. regarded a "members only" contract as an achievement testifies eloquently as to the status of the union.

However, the outbreak of war in Europe and American rearmament resulted in a sharp improvement in employment, and made it possible for the union to resume its forward march. One of the principal holdouts was Bethlehem Steel, the second largest producer in the

1 Robert R. R. Brooks, op. cit., p. 162.

2 Steel Labor, February 23, 1940, p. I. 
industry. In August, 1939, a campaign patterned on the 1937 drives had been undertaken against the company, aimed at the capture of its company unions. But the results were meager. In the words of a close student of the S.W.O.C., "the methods used in early S.W.O.C. campaigns had become stale. The enthusiasm built up by the whirlwind successes of the 1937 campaign had been dissipated in the futile and unplanned strike against Bethlehem's Cambria plant. Disillusion and disinterest were the inevitable aftermath. Early in 1940 there were no signs of anything like the almost hysterical enthusiasm of 1937. Consequently, the organizing campaign against Bethlehem was settling down to a long-run educational program in which the primary emphasis was on the development of leaders from the bottom up, and detailed training in the elementary techniques of collective bargaining." 1

The drive was renewed in October, 1940, when Van A. Bittner was put in charge. Bittner was one of the outstanding organizational leaders of the C.I.O.; coming from the Miners' Union, he had become Western director of the S.W.O.C. as well as director of the Packinghouse Workers' Organizing Committee. Short, effective strike demonstrations at several mills of Bethlehem, those at Lackawanna, N. Y., Johnstown, Pa., and Los Angeles, Calif., attested to the growing power of the union. The issue which served as an excuse for the demonstration was refusal of the company to discuss grievances with the S.W.O.C. The first real breakthrough came when employees at Bethlehem's Lackawanna plant, on May I 5, I94I, voted 8,223 to 2,961 in favor of the S.W.O.C. in an N.L.R.B. election. This was followed by similar results at the remaining Bethlehem mills during the ensuing year. The big mill at Johnstown voted 8,940 to 2, 108 for the S.W.O.C. The largest adverse vote came at Bethlehem, Pa., where 5,095 voters favored an independent union to 11,535 for the S.W.O.C. ${ }^{2}$ By the middle of r94I, the employees of Bethlehem Steel had demonstrated conclusively that they wanted the S.W.O.C. to represent them.

The momentum of the Bethlehem drive carried over into the remaining Little Steel companies. On July 25, I94r, Republic Steel, Inland Steel, and Youngstown Sheet and Tube agreed to abide by the results of an N.L.R.B. crosscheck of S.W.O.C. membership cards against their payrolls, thus avoiding the necessity of elections. The tally revealed that at 17 Republic plants, the S.W.O.C. had 28,482 members in good standing out of total employment of 40,858 ; at Inland, 8,700 out of 11,800 ; and at Youngstown Sheet and Tube, 14,800 out of $20,133 .^{3}$ The S.W.O.C. was thus entitled by law to

1 Robert R. R. Brooks, op. cit., p. I47.

2 Vincent Sweeney, op. cit., p. 48.

3 Steel Labor, August 29, I94I, p. I. 
become the exclusive collective bargaining agent of all the employees of these companies. In September, 194I, the four Little Steel companies sat down to bargain with officials of the union which four years earlier had been defeated so decisively.

In the meantime, in Januaty, I940, the S.W.O.C. asked U.S. Steel for the first substantial contract improvement since the original agreement of 1937 . At this time the industry was running at virtually full ingot capacity, and while employment was below the peak 1937 level, this was a consequence of technological change rather than idle resources. For the first time in its dealings with U.S. Steel, the union was in a position to exert a considerable degree of economic power.

The demands of the S.W.O.C. were far-reaching, and included a wage increase of ro cents per hour, an improvement in vacation rights and in the grievance system, a dues checkoff, and, most important from the union point of view, exclusive bargaining status on proof of majority through card crosscheck or by other means. ${ }^{1}$ The company countered with an offer of a $2 \frac{1}{2}$ cent an hour wage increase, tied, however, to production, so that when production dropped below 8 s per cent of capacity, the company would be privileged to withdraw the increase. On April i 4, a settlement was reached, giving the workers a wage increase of ro cents per hour, more liberal vacations, extra pay for holiday work, and additional subsidiary benefits. An elaborate mechanism for the processing of grievances was established. But on one important point, the union was unsuccessful: the "membersonly" feature of the original Taylor formula remained unchanged. Within a few months the wage pattern set by this agreement had spread to the entire industry.

The collective bargaining negotiations with the Little Steel companies proved to be long and arduous. Initially, the union demanded wage increases sufficient to bring the wage levels of these companies up to the levels prevailing in union plants, exclusive representation (to which the unions were entitled by law), and other provisions similar to those contained in the U.S. Steel contract. In one major respect, the union demands went beyond that contract: they included the union shop and the checkoff.

Before the negotiations had been consummated, the nation was thrown into war, and the dispute was referred to the newly created War Labor Board. In its award, the Board granted a wage increase of $5 \frac{1}{2}$ cents an hour under the famous "Little Steel Formula", and what was much more important to the union, maintenance of membership and a checkoff of union dues. Under the exigencies of the war econo-

I Steel Labor, March 20, 194I, p. I. 
my, the companies were obliged to accept this award, although not without bitter protest. ${ }^{1}$

While the S.W.O.C. was engaged on the War Labor Board front with Little Steel, it turned to the N.L.R.B. for the exclusive bargaining status with U.S. Steel that had been denied it in the I94I contract revision. In March, 1942, it filed N.L.R.B. election petitions for all U.S. Steel subsidiaries. The union won about 90 per cent of the votes at these elections ${ }^{2}$; on September 5, 1942, the U.S. Steel Corporation granted it exclusive bargaining rights, and, upon directive order of the War Labor Board, to which the union had appealed, maintenance of membership and the checkoff. Only two major steel producers remained outside the union fold: American Rolling Mills, with I 5,000 employees, and Weirton Steel with I 2,000 employees. Approximately 90 per cent of the industry was organized on a basis that provided the union with a considerable degree of membership security.

In May, I942, a convention was held at which the S.W.O.C. and the old Amalgamated Association of Iron, Steel and Tin Workers were formally merged into the United Steelworkers of America. Duespaying membership had risen to about 500,000; 903 steel firms were under contract with the union, 175 of them under union shop agreements and 47 under maintenance of membership clauses. ${ }^{3}$ Thus, seven years after the loss of one of the most disastrous strikes in American labor history, the union emerged victorious in its quest for organization of the steel workers. Whether this could have been achieved in so short a time, indeed, if at all, without the favorable conjuncture of government assistance through the National Labor Relations Board and, even more important, the condition of full employment created by the war, is at least problematical.

I See, e.g., The Iron Age, July 30, I942, p. 93.

2 Steel Labor, June 30, 1942, p. 2.

3 United Steelworkers of America, Proceedings of the First Constitutional Convention, 1942, pp. 36, 41 . 